\title{
Pelvis Cancer pT2b TNM Finding v8
}

National Cancer Institute

\section{Source}

National Cancer Institute. Pelvis Cancer pT2b TNM Finding v8. NCI Thesaurus. Code C136599.

Pelvis cancer with tumor confined to one pelvic segment with extraosseous extension or two segments without extraosseous extension and measuring more than $8 \mathrm{~cm}$ in greatest dimension. (from AJCC 8th Ed.) 